\title{
PERILAKU SISWA SEBAGAI WARGA NEGARA YANG BAIK PADA PEMBELAJARAN PPKN DI MTS JAMIATUL HUDA KELAS VIII
}

\author{
${ }^{1}$ Suhardi \\ ${ }^{2}$ Fitri Silvia Sofyan \\ ${ }^{3}$ Erwin Susanto \\ Universitas Buana Perjuangan Karawang \\ 1pk15.suhardi@mhs.ubpkarawang.ac.id \\ ${ }^{2}$ fitrisofyan@ubpkarawang.ac.id \\ ${ }^{3}$ susanto@ubpkarawang.ac.id
}

\begin{abstract}
This study aims to determine the condition of student behavior as good citizens among students in PPKn learning at MTs Jamiatul Huda class VIII. This research uses a qualitative approach with descriptive methods. The subjects of this study were class VIII of MTs Jamiatul Huda. Data collection techniques used interview respondents on the subjects of Pancasila and Civic Education (PPKn). The data analysis technique used the results of interviews, observation and documentation with triangulation. The results showed that the condition of student behavior as good citizens in MTs Jamiatul Huda Bekasi Regency, according to the results of data processing obtained in the field, it can be concluded that student behavior is said to be in accordance with the expectations of the fathers and mothers of teachers and parents.
\end{abstract}

Keywords: Student Behavior, Citizen Behavior, Civics Learning

\begin{abstract}
ABSTRAK
Penelitian ini bertujuan untuk untuk mengetahui kondisi perilaku siswa sebagi warga negara yang baik di kalangan siswa pada pembelajaran PPKn di MTs Jamiatul Huda kelas VIII. Penelitian ini menggunakan pendekatan kualitatif dengan metode deskriptif. Subjek penelitian ini adalah MTs Jamiatul Huda kelas VIII. Tenknik pengumpulan data menggunakan wawancara responden pada mata pelajaran Pendidikan Pancasila dan Kewarganegaraan (PPKn). Teknik analisis data dengan hasil wawancara, observasi dan dokumentasi dengan triangulasi. Hasil penelitian menunjukan bahwa kondisi perilaku siswa sebagai warga negara yang baik di MTs Jamiatul Huda Kabupaten Bekasi, sesuai dengan hasil pengolahan data yang di dapatkan dilapangan dapat di simpulkan bahwa perilaku siswa dikatakan sesuai dengan harapan bapak dan ibu guru serta orang tua.
\end{abstract}

Kata Kunci : Perilaku Siswa, Perilaku Warga Negara, Pembelajaran PPKn 


\section{PENDAHULUAN}

Guru yang merupakan tenaga pendidik khusus di angkat dengan tujuan utama mengajar pada jenjang pendidikan dasar dan jenjang pendidikan menengah. Tugas guru berkaitan dengan bidang propesi, kemanusiaan dan kemasyarakatan. Maka dari itu, tugas pokok seorang guru mendidik, mengajar dan melatih. Pada hakikatnya guru adalah salah satu komponen dalam sistem pendidikan yang sangat mempengaruhi hasil pendidikan.

Dalam pelaksanaan tugasnya guru telah diberi sembilan kode etik guru, menurut Donni Juni Priansa (2018, 87) Sembilan kode etik guru adalah :

“(1) Guru berbakti membimbing peserta didik untuk membentuk manusia Indonesia seutuhnya yang berjiwa Pancasila. (2) Guru memiliki dan melaksanakan kejujuran professional.

Guru berusaha memperoleh informasi tentang peserta didik sebagai bahan melakukan bimbingan dan pembinaan. (4) Guru menciptakan suasana sekolah sebaik-baiknya yang menunjang berhasilnya proses belajar-mengajar. (5) Guru memelihara hubungan baik dengan orang tua murid dan masyarakat sekitarnya untuk membina peran serta dan rasa tanggung jawab bersama terhadap pendidikan. (6) Guru secara pribadi dan bersamasama mengembangkan dan meningkatkan mutu dan martabat profesinya. (7) Guru memelihara hubungan seprofesi, semangat kekeluargaan, dan kesetiakawanan sosial. (8)
Guru secara bersama-sama memelihara dan meningkatkan mutu organisasi PGRI sebagai sarana perjuangan dan pengabdian. (9) Guru melaksanakan segala kebijakan Pemerintah dalam bidang pendidik".

Guru harus mematuhi sembilan kode etik guru. Pemerintah sangat selektif sekali melalui penyaringan calon pegawai negeri sipil dengan persyaratan-persyaratan yang begitu banyak harus di tempuh oleh para calon guru tersebut baik persyaratan pribadi maupun akademis dan pemerintah hanya mengangkat guru yang memenuhi persyaratan.

Guru harus memahami peraturan perundang-undangan tersebut sebagai pedoman dan acuan dalam melaksanakan tugasnya sehingga penyimpangan dapat dihindari. Guru harus menjadi figur bagi masyarakat (siswa) karena pendidikan merupakan keharusan bagi manusia, baik sebagai mahluk individu maupun sebagai makhluk sosial. Ini berarti pendidikan merupakan suatu kebutuhan hidup yang menjadi hak asasi manusia yang harus dilindungi. Setiap individu mempunyai hak yang sama untuk mendapat pendidikan dan pengajaran. Oleh karena itu, dalam penyelenggaraan pendidikan diperlukan ketentuan hukum dan peraturan oleh negara dan pemerintah.

Kondisi yang terjadi adalah masih terdapat guru yang melakukan tindakantindakan tidak profesional, tidak terpuji, bahkan melakukan tindakan-tindakan tidak senonoh yang dapat merusak citra dan martabat guru, misalnya guru yang mengenakan busana tidak sesuai dengan etika, tutur kata guru yang kurang normatif, serta beberapa kasus-kasus yang diberitakan diberbagai media. 
Pendidikan Pancasila dan Kewarganegaraan (PPKn) ialah salah satu mata pelajaran yang memfokuskan pada pembentukan karakter yang beragam dari segi agama, sosial, kultur, bahasa, usia dan suku bangsa untuk menjadi warga negara Indonesia yang cerdas, terampil dan berkarakter yang diamanatkan oleh Pancasila dan Undang-Undang Dasar 1945.

PPKn sebagai salah satu mata pelajaran yang wajib diselenggarakan disetiap jenjang pendidikan memiliki visi dan misi sebagai pedoman pelaksanaan dalam pembelajaran. Adapun visi dan misi PPKn adalah sebagai berikut:

"Menanamkan komitmen yang kuat dan konsisten terhadap prinsip dan semangat kebangsaan dalam kehidupan bermasyarakat, berbangsa dan bernegara yang berdasarkan Pancasila dan UndangUndang Dasar 1945 guna memberikan pemahaman yang mendalam tentang NKRI. Misi dari PPKn ialah menghindarkan Indonesia dari sistem pemerintahan otoriter yang memasung hak-hak warga negara untuk menjalankan prinsip-prinsip demokrasi dalam kehidupan bermasyarakat, berbangsa, dan bernegara (BNSP, 2006: 155)".

Sejalan dari tujuan sembilan (9) kode etik guru dan amant Undang-undang, maka seorang guru PPKn diharapkan mampu mengimplementasikan kompetensi-kompetensi yang dimiliki sebagaimana PPKn berfungsi untuk mengembangkan kemampuan dan sikap rasional siswa dalam menanggapi kenyataan atau permasalahan sosial serta perkembangan masyarakat Indonesia maupun masyarakat dunia pada masa lampau, masa kini, dan masa mendatang.
Penelitian ini menggunakan pendekatan kualitatif, maka hasil penelitian ini bersifat analisis-deskriptif yaitu berupa kata-kata tertulis atau lisan dari perilaku yang diamati terutama terkait dengan bagaimana perilaku siswa sebagai warga negara yang baik dikalangan siswa pada pembelajaran PPKn Kelas VIII MTs Jamiatul Huda.

Subjek penelitian ini terdiri dari kepala sekolah, guru PPKn dan enam (6) orang siswa. dari MTs Jamiatul Huda kelas VIII. Objek penelitian peneliti yaitu mengenai perilaku siswa sebagai warga negara dalam pembelajaran PPKn.

Teknik pengumpulan data merupakan cara yang digunakan peneliti untuk mendapatkan data dalam suatu penelitian. Teknik pada penelitian ini terdiri dari ; Wawancara, Pengamatan/Observasi, Dokumentasi, dan Triangulasi. Analisis data dalam penelitian kualitatif dilakukan sejak sebelum memasuki lapangan, selama di lapangan dan setelah selesai di lapangan, lalu melakukan reduction (reduksi data), display (penyajian data), dan Conclusion drawing/verification.

\section{HASIL DAN PEMBAHASAN}

Warga negara yang baik adalah yang memiliki kepedulian terhadap keadaan yang lain, memegang teguh prinsisp etika dalam berhubungan dengan sesama, berkemampuan untuk mengajukan gagasan dan ide-ide kritis, dan berkemampuan membuat menentukan pilihan atas dasar pertimbanganpertimbangan yang baik.Perilaku siswa sebagai warga negara yang baik di perlihatkan kepada guru dengan cara menjawab salam, membaca doa sebelum mulai pembelajar, menghormati guru dan mencontoh keteladan guru. Peduli dengan teman sebaya dan bertanggung jawab dalam perkataan dan perbuatan.

\section{METODE}


Cinta tanah air, menghargai bangasa Indonesia, menghargai bendera Indonesia dan menghargai perbedaan membuktikan siswa menjadi warga negara yang baik dan Ikut memperingati hari-hari besar Indonesia itu salah satu contoh warga negara yang baik bagi siswa. keteladanan seorang guru dengan cara guru datang dengan tepat waktu ke kelas bisa di contoh oleh siswa untuk datang tepat waktu. guru PPKn mencontohkan keteladanan di kelas dan di lingkungan sekolah bisa terlihat oleh semua siswa untuk mengikuti keteladana dan menjadi panutan. Dari keteladan guru tersebuat siswa bisa menjadi warga negara yang baik. Pembiasaan atau habituasi dapat dilakukan di sekolah dalam upaya mengembangkan karakter dan watak kewarganegaraan (Susanto \& Komalasari, 2015).

Manusia cakap adalah manusia yang cerdasa, trampil, serta sehat jasmani dan rohani, cakap berati pula sehat jasmani dan rohani yang artinya secara fisik pisikis sudah matang, kepribadian, berdisiplin, mau bekerja keras, tangguh, mandiri seta bertanggung jawab tugas dan pekerjaan. Hal tersebut sudah di contohkan oleh guru dan telah diikuti oleh siswa. Cakap adalah salah satu karakteristrik warga negara yang baik selaras dengan yang di kemukakan oleh Sulasmono (1989:178) yang menyatakan bahwa:
a. Cakap
b. Mengikuti kemuliaan setiap individu dan mengakui bahwa setiap orang memiliki kebutuhan fisik, social dan emosional yang harus dipenuhi demi perkembangan pribadinya, sehingga mampu hidup secara demokrasi
c. Tidak bersikap diskriminatif terhadap orang lain
d. Mengetahui prinsip- prinsip demokrasi serta perbedaanya dengan sistem totaliter
e. Menyadari keunikan demokrasi
f. Mengetahui sejarah perjuangan
g. Mempunyai
filsapat/pandangan hidup yang cocok dengan nilai-nilai demokrasi
h. Menyadari permasalahan sosial yang ada, serta bersedia dan mampu bekerja sama dalam menangani masalah- masalah sosial
i. Menyadari hak-hak politik dan kewarganegaraannya, serta menerima kewajiban-kewajiban politik dan kewarganegaraannya
j. Mematuhi hukum dan aturan dalam masyarakat, maupun negara dan bertindak legal dalam mengubah hukum/peraturan jika perlu.

Karakteristrik warga negara yang baik yang di kemukan diatas menunjukan siswa haus cakap, mengetahui sejarah perjuangan dan berdemokrasi, kegiatan berdemokrasi di dalam kelas di contohkan dengan pemilihan kepeutusan, pemilihan ketua kelas. Semua siswa harus demokrasi itu salah satu untuk menjadi warganegara yang baik. Siswa yang demokrasi selaras 
dengan pendapat Kaelan (1999:141) sebgai berikut: "secara umum didalam sistem pemerintahan yang demokratis senantiasa mengandung unsur-unsur yang paling penting dan mendasar yaitu:
a. Keterlibatan warga negara dalam keputusan politik
b. Tingkat persamaan warganegara tentang diantara
c. Tingkat kebiasan atau kemerdekaan warga negara tentang yang diakui dan dipakai oleh
d. Suatu sistem perwakilan
e. Suatu sistem pemilihan kekuasaan mayoritas".

Demokrasi melibatkan siswa untuk memberikan keputusan politik, siswa dilibatkan dalam keputusan politik di tingkat sekolah untuk proses belajara dari hal yang paling dasara pemilihan ketua kelas dan yang paling besar pesta demokrasi di tingkat pemilihan osis. Siswa belajar demokrasi untuk pengalam sebelum terjun kepada masyarakat. Perilaku siswa sebagai warga negara yang baik dibantu dengan pembelajaran PPKn, proses pembelajaran PPKn memberikan pengetahuan tentang menjadi warga negara yang baik karena di dalam pembelajaran PPKn mempelajari tentang menjadi warga negara yang baik.

Menurut Sumantri (2001 : 166) memberikan pemaparan mengenai fungsi PPKn sebagai berikut :

$$
\begin{array}{llr}
\text { "Usaha } & \text { sadar } & \text { yang } \\
\text { dilakukan } & \text { secara } & \text { ilmiah }
\end{array}
$$

dan psikologis untuk memberikan kemudahan belajar kepada peserta didik agar terjadi internalisasi moral Pancasila dan pengetahuan kewarganegaraan untuk melandasi tujuan pendidikan nasional, yang diwujudkan dalam integritas pribadi dan perilaku sehari-hari”.

Dilanjutkan dengan (Depdiknas, 2006:2) menyatakan bahwa fungsi dan tujuan dari mata pelajaran PPKn adalah :

"Sebagai wahana untuk membentuk warga negara yang baik (to be good citizenship), cerdas, terampil dan berkarakter yang setia kepada bangsa dan negara Indonesia yang merefleksikan dirinya dalam kebiasaan berfikir dan bertindak sesuai dengan amanat Pancasila dan UUD 1945".

Berdasarkan pada fungsi tersebut, maka pelajaran PPKn harus dinamis dan mampu menarik perhatian peserta didik, yaitu dengan cara sekolah membantu peserta didik mengembangkan pemahaman baik materi maupun keterampilan intelektual dan partisipatori dalam kegiatan sekolah yang berupa intrakulikuler dan ekstrakulikuler. Salah satu proses pembentukan warga negara yang baik, Pembentukan warga negara yang baik menjadi salah satu misi utama pendidikan nasional Indonesia. Salah satu mata pelajaran yang juga mengemban misi tersebut adalah Pendidikan Pancasila dan Kewarganegaraan (PPKn). Pemberian pembelajaran PPKn diberikan mulai dari jenjang pendidikan dasar sampai jenjang sekolah menengah atas. Dengan demikian, 
guru PPKn menjadi tulang punggung bagi tercapainya misi tersebut. Dengan kata lain, profesionalitas para guru PPKn merupakan salah satu factor keberhasilan misi tersebut.

\section{SIMPULAN}

Kondisi perilaku siswa sebagai warga negara yang baik di MTs Jamiatul Huda Kabupaten Bekasi, sesuai dengan hasil pengolahan data yang di dapatkan dilapangan dapat di simpulkan bahwa perilaku siswa dikatakan sesuai dengan harapan bapak dan ibu guru serta orang tua.

\section{DAFTAR PUSTAKA}

Akhiya Huddin Mn. (2017). Keteladan Guru Dalam Proses Pendidikan Di kelas IV SD NEGERI NO.28/I MALAPARI MUARA BULIAN

Cahyono \& suparyo, w. (1985). Tahaptahap perkembangan moral. Malang: IKIP Malang Juni

Ihsan (2017). Kecenderungan Global Dalam Proses Pembelajaran Pendidikan Pancasila Dan Kewarganegaraan Di Sekolah. Jurnal Pancasila dan Kewarganegaraan. Vol. 2, No. 2, Hal. 49-58

Kaelan. 1999. pendidikan pancasila yuridis kenegaraan. Yogyakarta: penerbit paradigma

Lutfaidah, Anna. (2016). Kajian Moral dan Kewarganegaraan. Jurnal Pembelajaran PPKn bagi Anak Berkebutuhan Khusus.Vol. 02, No. 04, Hal. 813-828

Priansah, D. (2018). Kinerja dan Profesonalisme guru .Bandung: CV. Alfabeta
Priansa, D, J. (2018). Kinerja dan propesionalisme guru. Bandung: CV. Alfabeta

Rusyandy, T. (1996). Menjadi guru teladan. Cianjur. Cipta Karya

Shoimin, Aris. (2014). Guru Berkarakter Untuk Implementasi Pendidikan Karakter. Yogyakarta: Gava Media

Siti Masyitoh Lim. (2008). Memahami pendidikan Kewarganegaraan. Bandung.CV Yasindo Multi Aspek

Sulasmono, B, S. (1989). Dasar Negara Pancasila. Bandung. Kanisius

Sumantri. (2001). Pembaharuan pendidikan IPS. Bandung: Rosda Karya

Sugiyono. (2017). Metode Penelitian Kuantitatif, kualitatif dan $R \& D$. Bandung: Alfabeta.

Sugiyono. (2013). Metode Penelitian Kuantitatif, kualitatif dan $R \& D$. Bandung: Alfabeta CV. Bandung

Suyono, dkk. 2015. Upaya pembentukan warga negara yang baik dan tangtangan yang dihadapi oleh para guru PPKn

Uzer, Moh, Usman. (2011). Menjadi Guru Profesional. Bandung: PT. Remaja Rosdakarya.

Undang-undang Nomor 14 tahun 2005 tentang Guru dan Dosen PP Nomor 22 Tahun 2006 Tentang Standar Isi meliputi aspek-aspek Undang-Undang Republik Indonesia Nomor 20 Tahun 2003 Tentang : Sistem Pendidikan Nasional 